\title{
Analisis Kepuasan Pengunjung Wisata Islamic Centre Kabupaten Rokan Hulu
}

Umi Hani ${ }^{1}$

Manajemen, Universitas Pasir Pengaraian, Rokan Hulu, Riau

\section{Info Artikel}

Sejarah Artikel:

Diterima 14 Januari

2019

Disetujui 21 Maret 2019

Dipublikasikan 15 Juni

2019

Keywords:

Islamic Center, Rokan

Hulu, Satisfaction

\begin{abstract}
Abstrak
Penelitian ini membahas tentang Analisis Kepuasan Pengunjung Wisata Islamic Centre Kabupaten Rokan Hulu. Tujuan dari penelitian ini adalah Bagaimana Pengaruh Kepuasan Pengunjung Wisata Islamic Centre Kabupaten Rokan Hulu. Populasi dalam penelitian ini Pengunjung Wisata Islamic Centre Kabupaten Rokan Hulu yang berjumlah 100 orang responden. Teknik penentuan sampel yang digunakan adalah simple random sampling dimana setiap masyarakat yang berkunjung ke Islamic Center Kabupaten Rokan Hulu dijadikan populasi mempunyai kesempatan yang sama untuk diseleksi sebagai sampel. Hasil penelitian menunjukkan bahwa variabel kepuasan pengunjung pada indikator lokasi islamic yang tertinggi menjawab puas sebanyak (53\%) dan tidak puas sebanyak (47\%). Indikator fasilitas islamic yang tertinggi menjawab puas sebanyak $(67 \%)$ dan tidak puas sebanyak (33\%). Indikator kenyamanan pengunjung yang tertinggi menjawab puas sebanyak $(82 \%)$ dan tidak puas sebanyak $(18 \%)$. Hal ini dapat terlihat dari hasil distribusi jawaban responden penelitian. Sehingga hipotesisnya adalah terdapat pengaruh tingkat kepuasan pengunjung wisata islamic centre Kabupaten Rokan Hulu.
\end{abstract}

ANALYSIS OF ISLAMIC CENTER VISITORS' SATISFACTION ROKAN HULU REGENCY

\begin{abstract}
This study discusses the Analysis of the Satisfaction of Islamic Visitor Center for Rokan Hulu District. The purpose of this research is How to Influence Satisfaction of Islamic Visitor Center in Rokan Hulu Regency. The population in this study was Islamic Center Tourism Visitors in Rokan Hulu Regency, amounting to 100 respondents. The technique of determining the sample used is simple random sampling where each community visiting the Rokan Hulu District Islamic Center as a population has the same opportunity to be selected as a sample. The results showed that the highest visitor satisfaction variable in the Islamic location indicator answered as much as (53\%) and dissatisfied as much (47\%). The highest indicator of Islamic facilities answered satisfied as much (67\%) and dissatisfied as much (33\%). The highest comfort indicator for visitors answered satisfied (82\%) and dissatisfied as much (18\%). This can be seen from the results of the distribution of answers to the research respondents. So the hypothesis is that there is an influence on the level of satisfaction of visitors to the Islamic center of Rokan Hulu Regency.
\end{abstract}

\begin{tabular}{|c|c|}
\hline Alamat korespondensi : & ISSN \\
\hline Isikan alamat institusi & $\mathrm{xxxx}-\mathrm{xxxx}($ cetak) \\
\hline E-mail: (email yang ditulis adalah email penulis yang berkorespondensi dengan editor) & xxxx-xxxx (online) \\
\hline
\end{tabular}




\section{PENDAHULUAN}

\section{A. Latar Belakang}

Pariwisata merupakan perjalanan dari satu tempat ke tempat lain, bersifat sementara, dilakukan perorangan atau kelompok, sebagai usaha mencari keseimbangan atau keserasian dan kebahagiaan dengan lingkungan hidup dalam dimensi sosial, budaya, alam dan ilmu. Kegiatan melakukan perjalanan dengan tujuan mendapatkan kenikmatan, mencari kepuasan, mengetahui sesuatu, memperbaiki kesehatan, menikmati olahraga atau istirahat, menunaikan tugas, dan lainlain disebut dengan pariwisata.

Tabel pengunjung wisata islamic centre Kabupaten Rokan Hulu:

\begin{tabular}{|c|c|c|}
\hline No & Tahun & Jumlah Pengunjung \\
\hline 1. & 2012 & 20 Orang \\
\hline 2. & 2013 & 270 Orang \\
\hline 3. & 2014 & 648 Orang \\
\hline 4. & 2016 & 6609 Orang \\
\hline 5. & 2017 & 47.744 Orang \\
\hline \multicolumn{2}{r|}{ Jumlah } & \\
\hline
\end{tabular}

Data: Islamic Center Kabupaten Rokan Hulu 2012 $-2017$

Dari data diatas dapat kita tarik kesimpulan bahwa banyaknya pegunjung yang ingin berwisata ke Islamic Center Kabupaten Rokan Hulu dari tahun ketahun megalami peningkatan sesuai dengan data yang diperoleh dimana pada tahun masa pemerintahan Bupati Rokan Hulu Dr, Ahmad, M.Si megatakan bahwa Islamic Center akan berkembang beberapa tahun kedepan sesuai dengan keadaan yang ada disaat sekarang ini bisa kita lihat data diatas dari tahun 2012 jumlah pengunjung yaitu 20 orang, tahun 2013 berjumlah 110 orang, tahun 2014 jumlah pegunjung sebesar 270 orang, tahun 2015 jumlah pengunjung mulai meningkat yaitu sebesar 648 orang, sedangkan tahun 2016 sekarang pengunjung mulai meningkat 40.090 orang, sebelum berkunjung para pengunjung mempelajari dan mencari informasi tentang kondisi dan bentuk Islamic Center Kabupaten Rokan Hulu, serta para pengunjung sebelum berkunjung keislamic center para pengunjung telah memberikan informasi kepetugas Islamic.

Memahami aspek kepuasan masyarakat merupakan hal yang sangat penting, karena pada dasarnya sebuah objek wisata sebenarnya harus mengetahui dan memahami sudah sejauh mana kemampuannya dalam memenuhi kebutuhan para wisatawan secara komprehensif, sehingga diharapkan akan ada upaya perbaikan secara continue di mana akan tercapai sasaran yang diinginkan yaitu menjadi Islamic yang berkualitas dengan sendirinya akan mengharumkan nama Rokan Hulu sendiri. Selain itu pentingnya memahami aspek kepuasan pengunjung adalah bahwa realitas pengunjung yang tidak puas cenderung akan memberikan respon negatifnya 
terhadap wisata islam, berbagai perilaku akan dimunculkan, keadaan kelemahan-kelemahan institusi cenderung akan diceritakan yang bisa saja akan memburukkan citra sebuah institusi dimata publik. Kepuasan masyarakat berkunjung ke Islamic Center Kabupaten Rokan Hulu tergantung pada fasititas dan bentuk keadaan yang dilihat, sebenarnya pengunjung harus mengetahui dan memahami sudah sejauh mana keberasilan dari Islamic center Kabupaten Rokan Hulu dalam memenuhi kebutuhan pengunjung secara komprehensif sehingga para pengunjung wisata religi merasa puas dengan keadaan yang ada, kepuasan pengunjung tergantung apa yang didapatkan para pengunjung, pengunjung merasa puas dengan apa yang mereka rasakan, mereka lihat, mereka nikmati, dengan keadaan yang ditemukan maka pengunjung akan menceritakan dengan masyarakat lain, dengan mereka bercerita maka masyarakat lain akan berkunjung ke Islamic Center Kabupaten Rokan Hulu. Adapun indikator dari variabel penelitian ini adalah kesesuaian harapan lokasi Islamic adalah posisi pasti dalam ruang dalam sistem coordinator yang sesuai. Fasilitas Islamic adalah Segala sesuatu yang dapat memudahkan dan memperlancar pelaksanaan suatu usaha dapat berupa pelayanan dan sarana prasarana. Kenyamanan berkunjung adalah Suatu keadaan telah terpenuhi kebutuhan dasar yang diharapkan para pengunjung. Hasil survei yang didapatkan peneliti terhadap beberapa responden pengunjung bahwa kepuasan yang didapatkan dari kunjungan ke Islamic center Kabupaten Rokan Hulu adalah dimana para pengunjung mereka merasa senang karena seakan-akan melaksanakan sholat di masjid arab yaitu masjid nabawi, bentuk atau rupa mesjidnya yang bagus, serta keunikan masjidnya, sehingga pada tanggal 6 Desember masjid Islamic center mendapatkan penghargaan dari Mentri agama yaitu menjadi masjid yang terbaik di Indonesia, serta bekerja sama dengan masjid istiqal Jakarta. Kekurangan yang dirasakan pengunjung yaitu banyaknya para pedagang yang berkeliaran, dimana para pedagang yang berjualan di Islamic Center tersebut tidak pada tempatnya dimana kita jumpai para pedangang asongan yang mengunakan tanpa atau mengunakan gendongan, pedagang berkeliling diareal Islamic center terutama pada bagian pintu utama, air mancur, serta didekat areal menara $99 \mathrm{M}$, sehingga membuat suasana kurang yaman dipandang oleh mata, dengan adanya pedagang yang berkeliaran membuat para pengunjung ada yang suka dan ada yang tidak suka atas kehadiran para pedagang, pedagang yang berkeliran banyak membuat para pengunjung merasa risih, kurang nyaman, kurang enak dipandang dikarenakan para pengunjung merasa terganggu atas kehadiran para pedagang di depan mereka sehingga para pengunjung susah untuk berfoto dan selfie di Islamic center tersebut, adapun 
para pedagang yang menggunakan asongan atau gendongan adalah pedagang es tebu, es kelapa, es campur, dan minuman lainnya. Pedagang yang berjualan dengan mengunakan gendongan atau asongan adalah kebanyakan anak- anak dibawah umur yang tidak kenal degan tata kerama dan etika.

Sampah berserakan, dengan banyaknya pedagang asongan yang berkeliling di areal masjid membuat sambah menumpuk membuat suasana kurang kondusif, kurang yaman, kurang enak dipandang mata, melihat sampah suatu benda yang berbau, jorok tidak enak dipandang mata, dengan adanya sampah banyak menimbulkan lalat, sampah berserakan membuat pegunjung susah untuk selfie dan berfoto didaerah Islamic para pengunjung ingin merasa suasana nyaman dan enak dipandang oleh mata dengan adanya sampah membuat kurang nyaman dalam berkunjung ke Islamic para pengunjung menginginkan areal masjid yang asri rindang dan bersih. Serta tersedianya kapasitas air yang ada di masjid tidak terpenuhi sesuai kapasitas pengunjung Islamic yang ramai, Kesan yang didapatkan pengunjung adalah imam masjid yang pasef membaca al-Qur'an dengan baik dan benar, Islamic center Kabupaten Rokan Hulu juga mempunyai kelebihan dari pada masjid- masjid lain yang ada di Indonesia dimana masjid Islamic Center Kabupaten Rokan Hulu mengadakan pegajian atau program magrib mengaji.
Permasalahan yang ditemukan peneliti adalah ketidaknyaman pegunjung terhadap fasilitas yang ada seperti mengantri disaat mau menaiki menara $99 \mathrm{M}$, kurangnya pemadu wisata sehingga para wisatawan tidak bisa mengelilingi Islamic Center tersebut, serta seringnya air mati karena ramainya para pengunjung maka kapasitas air yang ada di masjid tidak dapat terpenuhi sesuai kapasitas yang ada air tempat berwuduk terkadang debit air kurang deras ketika pengunjung Islamic yang ramai, sehinga para pengunjung terpaksa mengantri ketika mau berwuduk, serta tidak adanya tanda sebagai penunjuk arah yang di berikan oleh pihak Islamic Center sehingga para pengunjung sering tersesat, pengunjung merasa kurang terealisasi parker untuk pengunjung yang datang dari daerah maupun luar daerah.

Saat ini setiap hari sangat ramai yang datang berkunjung ke masjid ini.bahkan, wisatawannya bukan saja dari dalam negeri, tapi juga ada yang dari luar negeri seperti Malaysia dan negara Timur Tengah.Berdasarkan latar belakang ini, maka perlu untuk meneliti lebih lanjut mengenai Analisis Kepuasan Pengunjung Wisata Islamic Center Kabupaten Rokan Hulu.

\section{KAJIAN TEORI}

\section{A. Kepuasan Pelanggan (Pengunjung)}

Kepuasan Pelanggan adalah kinerja suatu barang atau jasa yang sekurang-kurangnya sama dengan 
apa yang diharapkan, Pelanggan yang tidak pernah mengajukan keluhan (complain) bukan berarti Pelanggan tersebut merasa puas, namun mereka akan beralih ke produk perusahaan lain tanpa mengonfirmasikan keberatannya. Pelanggan yang berani mengungkapkan ketidakpuasannya seringkali justru Pelanggan yang setia. Terciptanya kepuasan Pelanggan akan memberi manfaat kepada perusahaan karena pembeli merasa terpenuhi keinginannya dan kebutuhan akan membeli ulang (repeat buying) dan terciptnya loyalitas terhadap jasa pelayanan yang diterima, selain itu mereka akan lebih loyal terhadap harga serta akan merekomendasikannya dari mulut ke mulut kepada teman sekitarnya untuk menggunakan jasa tersebut dan menguntungkan perusahaan.

\section{B. Indikator Kepuasan Pengunjung atau pelanggan}

Menurut Tjiptono (2007: 89) indikator kepuasan pelanggan atau pengunjung adalah:

a. Lokasi Islamic

Adalah posisi pasti dalam ruang dalam sistem coordinator yang sesuai

b. Fasilitas Islamic

Adalah Segala sesuatu yang dapat memudahkan dan memperlancar pelaksanaan suatu usaha dapat berupa pelayanan dan sarana prasarana.

c. Kenyamanan berkunjung
Adalah Suatu keadaan telah terpenuhi kebutuhan dasar yang diharapkan para pengunjung.

\section{Pengertian Kualitas Pelayanan}

Sampara dalam Hardiyansyah (2011: 35-36) mendefenisikan kualitas pelayanan adalah pelayanan yang diberikan kepada pelanggan sesuai dengan standar pelayanan yang telah dibakukan sebagai pedoman dalam memberikan layanan.Seperti yang dietahui bahwa kualitas pelayanan dapat digunakan sebagai salah satu alat untuk mencapai keunggulan bersaing dan menentukan keberhasilan serta kualitas perusahaan. Semakin baik pelayanan yang diberikan dimata pelanggan berarti semakin tinggi pula tingkat keberhasilan dan kualitas perusahaan yang dicapai dan begitu pula sebaliknya.

Hal ini berarti ada dua faktor utama yang mempengaruhi kualitas pelayanan yaitu pelayanan yang diharapkan (expected service) dan pelayanan yang dipersepsikan (perceived service) Bila pelayanan yang diterima atau dirasakan sesuai dengan yang diharapkan, maka kualitas dapat dipersepsikan baik dan memuaskan. Jika kualitas pelayanan yang diterima melebihi harapan pelanggan, maka kualitas pelayanan dipersepsikan sebagai kualitas jasa yang ideal, akan tetapi bila kualitas pelayanan yang diterima lebih rendah daripada yang diharapkan, maka kualitas pelayanan dipersepsikan buruk. Jadi penilaian pelanggan 
mengenai kualitas pelayanan sangat bergantung pada kemampuan penyedia.

\section{Faktor-faktor yang mempengaruhi kualitas pelayanan}

Hardiyansyah (2011: 53-57) ada beberapa faktor yang mempengaruhi pelayanan publik yaitu :

a. Motivasi kerja karyawan, memiliki

pengaruh signifikan terhadap kualitas

pelayanan, dengan demikian untuk

memberdayakan aparatur birokrasi

diperlukan peningkatan motivasi kerja

sehingga kualitas pelayanan lebih

meningkat.

b. Prilaku organisasi, bentuk prilaku organisasi yang tidak sesuai dengan formalisasi dan norma-norma organisasi yang telah ditetapkan sehingga menyebabkan mutu pelayanan sangat rendah.

c. Komunikasi, iklim komunikasi organisasi berpengaruh positif terhadap pelaksanaan pelayanan, aliran informasi yang diberikan oleh petugas pelayanan harus tepatdan akurat sesuai dengan prosedur.

d. Efektifitas, tindak lanjut terhadap pelayanan yang meliputi : dimensi pemantauan, pemeriksaan, evaluasi, tindakan korektif dan tindakan dimensi kesederhanaan, kejelasan, keadilan, dan ketepatan waktu. e. Pengawasan masyarakat, komunikasi dan nilai masarakat berpengaruh terhadap kualitas pelayanan yang meliputi: keandalan, ketanggapan, keyakinan, empati dan wujud.

f. Tanggung jawab, diharapkan petugas pelayanan harus bertanggung jawab atas dokumen yang diterima dari pelanggan.

g. Kepemimpinan, pengawasan atasan suatu organisasi terhadap pelaksanaan tugas bawahannya, yaitu kepemimpinan yang diterapkan diharapkan dapat mendorong karyawannya untuk menampilkan kinerja yang baik.

Dari urain diatas menurut penulis kualitas pelayanan adalah : segala bentuk aktivitas yang dilakukian oleh perusahaan guna memenuhi harapan konsumen, berupa kemudahan, kecepatan, kemampuan dan keramah tamahan yang ditunjukkan melalui sikap dan sifat dalam memberikan pelayanan untuk kepuasan konsumen.

\section{E. Jenis dan Macam Pariwisata}

Menurut James(2008: 90) terdapat berbagai macam jenis pariwisata berdasarkan motif seseorang untuk melakukan perjalanan wisata. Perbedaan motif tersebut mempengaruhi preferensi seseorang untuk melakukan perjalanan wisata dan kemudian akan tercermin pada jenis pariwisata yang berbeda. Jenis dan macam pariwisata dijelaskan sebagai berikut : 
1. Pariwisata untuk menikmati perjalanan (Pleasure Tourism)Bentuk pariwisata ini dilakukan oleh orang-orang yang meninggalkan tempat tinggalnya untuk berlibur, untuk mencari udara segar yang baru, untuk memenuhi kehendak ingin tahunya, untuk mengendorkan ketegangan sarafnya, untuk melihat sesuatu yang baru, untuk menikmati keindahan alam, untuk menikmati hiburan di kota besar ataupun ikut serta dalam keramaian pusat wisatawan. Jenis pariwisata ini menyangkut banyak unsur yang sifatnya berbeda, disebabkan pengertian pleasure akan selalu berbeda kadar kepuasannya sesuai dengan karakter, cita rasa, latar belakang kehidupan, serta tempramen masing-masing individu.

2. Pariwisata untuk rekreasi (Recreation Tourism)Jenis pariwisata ini dilakukan oleh orang-orang yang menghendaki pemanfaatan hari liburnya untuk beristirahat, memulihkan kembali kesegaran jasmani dan rohani, dan yang ingin menyegarkan keletihan dan kelelahannya. Dengan kata lain mereka lebih menyukai health resort. Termasuk dalam kategori ini adalah mereka yang karena alasan kesehatan.dan kesembuhan harus tinggal di tempat khusus untuk memulihkan kembali kesehatannya.
3. Pariwisata untuk kebudayaan (Cultural Tourism)Jenis ini ditandai oleh adanya rangkaian motivasi, seperti keinginan untuk belajar di pusat pengajaran dan riset, untuk mempelajari adat istiadat, kelembagaan dan cara hidup rakyat negara lain, untuk mengunjungi monument bersejarah, peninggalan peradaban masa lalu atau sebaliknya penemuan besar masa kini, pusat kerajinan, pusat keagamaan atau juga untuk ikut serta dalam festival seni musik, teater, tarian rakyat dan lain-lain.

\section{METODE PENELITIAN}

Kerangka konseptual dalam penelitian merupakan penjelasan sementara fenomena terhadap objek yang jadi masalah yang akan diteliti yakni Kebutuhan dan keingginan,Survei kepuasan pelanggan, pengalaman dari temandalam penelitian ini, bagian dari kerangka konseptual akan menjelaskan bagaimanakah kepuasan pengunjung yang dirasakan oleh pengunjung Islamic Center Pasir Pengaraian, yang dapat dijelaskan pada gambar di bawah ini:

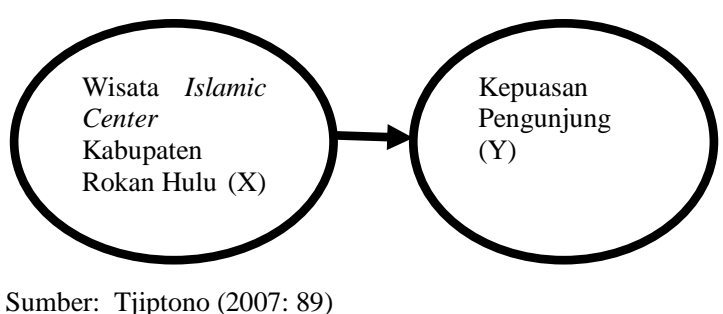

a. Ruang Lingkup Penelitian

Dalam penelitian ini peneliti menggunakan metode deskriptif kuantitatif dimana data yang digunakan 
sudah jelas, yaitu diarahkan untuk menjawab rumusan masalah yang telah dirumuskan dalam skripsi. Penelitian ini dilakukan di Islamic Center Kabupaten Rokan Hulu pada bulan Juni sampai Desember 2017.

\section{b. Populasi dan Sampel}

\section{Populasi}

Populasi adalah wilayah generalisasi yang terdiri atas: abjek/subyek yang mempunyai kualitas dan karakteristik tertentu yang ditetapkan oleh peneliti untuk dipelajari dan kemudian ditarik kesimpulannya. Sugiyono (2012 : 115) Populasi dalam penelitian ini adalah seluruh wisatawan yang mengujungi objek wisata religi yaitu Islamic Center Kabupaten Rokan Hulu yang berjumlah 47.747 orang.

\section{Sampel}

Sampel adalah sebagian dari jumlah karakteristik yang dimiliki oleh populasi tersebut.Atau dengan kata laian sampel 100 orang adalah sebagian dari populasi. Sugiyono (2012: 116).

Notoatmodjo, 2010 : 120 ) Pada penelitian ini peneliti mengambil sampel dengan tekhnik simple random sampling dimana setiap masyarakat yang berkunjung ke Islamic Center Kabupaten Rokan Hulu dijadikan populasi mempunyai kesempatan yang sama untuk diseleksi sebagai sampel. Dihitung dengan rumus Slovin:

$$
n=\frac{N}{1+N \cdot e^{2}}
$$

Dimana:

$$
\begin{aligned}
& \mathrm{n}=\text { Besar Sampel, } \\
& \mathrm{N}=\text { BesarPopulasi } \\
& \mathrm{e}=\text { Persentase kelonggaran akibat }
\end{aligned}
$$

kesalahan pengambilan sampel yang ditolerir.

Dalam penelitian ini digunakan kesalahan pengambilan sampel sebesar $10 \%$.

$$
\begin{array}{ll}
\mathrm{n} & =\frac{47.747}{1+47.747 .10 \%^{2}} \\
\mathrm{n} & =\frac{47.747}{1+47.747 \cdot 0,1^{2}} \\
\mathrm{n} & =\frac{47.747}{1+47.747 .0,01} \\
\mathrm{n} & =\frac{47.747}{478,47} \\
\mathrm{n} & =99,79 \text { dibulatkan } 100 \text { orang }
\end{array}
$$

\section{c. Defenisi Operasional}

Defenisi operasional adalah variabel penelitian dimaksudkan untuk pemahaman arti setiap variabel peneliti sebelum dilakukan analisi( Wiratna2014: 87). Kondisi-kondisi atau serenteristik-serenteristik yang oleh peneliti di manifullasikan, dikontrol, atau diobservasi dalam suatu penelitian. (Narbuko2010 : 118) yaitu Variabel faktor-faktor yang mempengaruhi Kepuasan Pengunjung Wisata Islamic Center Kabupaten Rokan Hulu. 


\begin{tabular}{|c|c|c|c|}
\hline $\begin{array}{l}\text { Variabel } \\
\text { Konsep }\end{array}$ & Variabel & Indikator & Skala \\
\hline kepuasan & $\begin{array}{l}\text { Kepuasan } \\
\text { konsumen adalah } \\
\text { proses } \\
\text { pengintegrasian } \\
\text { yang } \\
\text { mengombinasikan } \\
\text { pengetahuan } \\
\text { untuk } \\
\text { mengevaluasi dua } \\
\text { atau lebih prilaku } \\
\text { alternatif dan } \\
\text { memilih salah } \\
\text { satu diantaranya. } \\
\text { Hasil dari proses } \\
\text { pengintegrasian } \\
\text { ini ailah suatu } \\
\text { pilihan (choice), } \\
\text { yang disajikan } \\
\text { secara koknitif } \\
\text { sebagai keinginan } \\
\text { berprilaku. } \\
\text { Nugroho (2013 : } \\
\text { 342). }\end{array}$ & $\begin{array}{l}\text { 1. Lokasi } \\
\text { Islamic } \\
\text { 2. Fasilitas } \\
\text { Islamic } \\
\text { 3. Kenyamanan } \\
\text { pengunjung } \\
\text { Menurut } \\
\text { Tjiptono(2007: } \\
\text { 89) }\end{array}$ & Likert \\
\hline
\end{tabular}

\section{d. Teknis Analisis Data}

Ditinjau dari kepuasan pengunjung Islamic Center Kabupaten Rokan Hulu maka teknik analisis data yang digunakan adalah statistik deskriptif. Menurut sugiyono (2009) statistik deskriftif persentase yaitu data yang diolah dengan cara frekuensi jawaban dibagi dengan jumlah responden dikali 100 persen,adapun rumusnya sebagai berikut:

$$
\frac{F}{N} X 100 \%
$$

Keterangan:

$$
\begin{aligned}
& \mathrm{F}=\text { Frekuensi sampel } \\
& \mathrm{N}=\text { Jumlah seluruh skor ideal } \\
& \%=\text { tingkat keberhasilan yang dicapai } \\
& \text { Perhitungan deskriptif persentase ini }
\end{aligned}
$$
mempunyai langkah-langkah sebagai berikut:

1. Mengoreksi jawaban kuesioner dari responden

2. Menghitung frekuensi jawaban responden
3. Jumlah responden keseluruhan adalah 100 orang

4. Memasukkan jumlah tiap-tiap frekuensi jawaban kedalam rumus

Dari keterangan diatas dapat dijelaskan bahwa untuk mencari besar nilai efektivitas kepuasan pengunjung pada proses input yaitu perbandingan antara jumlah responden yang menjawab pertanyaan puas dengan jumlah responden yang menjawab tidak puas.

\section{HASIL PENELITIAN DAN PEMBAHASAN}

\section{A. Karakteristik Responden}

Hasil survei menunjukkan bahwa jumlah sampel penelitian berjumlah 100 orang responden. Bahwa pengunjung lebih banyak laki- laki dari pada perempuan sehingga pengunjung merasa puas atas keadaan yang ada di Islaimic Center Kabupaten Rokan Hulu dibuktikan dengan jumlah laki-laki (85\%) sedangkan perempuan (15\%). Rata-rata responden berdasarkan tingkat usia lebih banyak berusia muda sehingga kemampuan untuk berkunjung ke Islamic Center Kabupaten Rokan Hulu sangat baik. Hal ini bisa dilihat dari usia muda yang lebih tinggi yaitu 28-29 tahun sebanyak 36 orang responden (36\%). Karakteristik berdasarkan pendidikan bahwa rata-rata pengunjung Islamic Center Kabupaten Rokan Hulu Rata-rata SMA sederajat sebanyak 71 orang responden $(71 \%)$ sehingga pengunjung banyak berdatangan setiap minggunya, sedangkan 
pengunjung Islamic Center Kabupaten Rokan Hulu yang apaling rendah adalah DIII- sederajat yaitu sebesar 1 (1\%). Karakteristik berdasarkan pekerjaan disimpulkan bahwa sebagian besar responden dalam penelitian ini memiliki pekerjaan wiraswasta yaitu 35 orang responden $(35 \%)$ dan paling kecil memiliki pekerjaan sebagai pelajar/mahasiswa yaitu sebanyak 15 orang responden $(15 \%)$.

\section{B. Analisis Data}

Dalam penelitian ini terdiri dari analisis kepuasan pengunjung wisata islamic center Kabupaten Rokan Hulu yang di analisis adalah lokasi islamic, fasilitas islamic dan kenyamanan pengunjung.

Berdasarkan dari analisis unsur- unsur kepuasan pengunjung Islamic Center:

\section{Lokasi Islamic (P1)}

Dari hasil yang didapatkan peneliti diatas dari kategori lokasi Islamic Center maka didapatkan bahwa kepuasan pengunjung untuk berkunjung ke Islamic Center Kabupaten Rokan Hulu yang pertama penjelasan secara jelas tentang Islamic Center Kabupaten Rokan Hulu dengan jumlah frekuensinya jawaban puas yaitu (53\%), sedangkan menyatakan tidak puas yaitu (47\%). Jawaban kedua yaitu memberikan tontonan tentang proses pembutan Islamic Center dengan jumlah frekuensi jawaban puas (53\%) dan tidak puas (47\%), untuk jawaban yang ketiga adalah memberikan penjelasan tentang fropil Islamic Center dengan jumlah frekuensi jawaban puas (38\%) dan tidak puas $(62 \%)$.

\section{Fasilitas Islamic}

Dari hasil yang didapatkan peneliti diatas dari kategori lokasi Islamic Center maka didapatkan bahwa kepuasan pengunjung untuk berkunjung ke Islamic Center Kabupaten Rokan Hulu, pertanyaan pertama memberikan tempat penginapan secara gratis dengan jumlah frekuensinya jawaban puas yaitu (38\%), sedangkan menyatakan tidak puas yaitu (62\%). Jawaban kedua yaitu Naik menara 99 dengan cara membayar 5000/ orang dengan jumlah frekuensinya jawaban puas yaitu (67\%), sedangkan menyatakan tidak puas yaitu (33\%). Pertanyaan ketiga memberikan siraman rohani setiap saat waktu sholat telah selesai dengan jumlah frekuensinya jawaban puas yaitu (36\%), sedangkan menyatakan tidak puas yaitu (64\%).

\section{Kenyamanan Pengunjung}

Dari hasil yang didapatkan peneliti diatas dari kategori lokasi Islamic Center maka didapatkan bahwa kepuasan pengunjung untuk berkunjung ke Islamic Center Kabupaten Rokan Hulu yang pertama penjelasan secara jelas tentang memberikan pengunjung masuk secara gratis dantidak dipungut biaya dengan jumlah frekuensinya jawaban puas yaitu (82\%), sedangkan menyatakan tidak puas yaitu (18\%). Jawaban kedua yaitu Pengunjung selalu kehilangan sepatu atau alas 
kaki dengan jumlah frekuensinya jawaban puas yaitu (33\%), sedangkan menyatakan tidak puas yaitu (67\%). Pertanyaan ketiga Pengunjung selalu menjumpai air kran mati setiap mau berwuduk dengan jumlah frekuensinya jawaban puas yaitu (66\%), sedangkan menyatakan tidak puas yaitu $(34 \%)$.

Berdasarkan hasil wawancara dari semua pernyataan tentang kepuasan pengunjung Islamic Center Kabupaten Rokan Hulu diketahui dari variabel lokasi islamic terdapat pada pernyataan nomor 1 dan 2 dengan jawaban Puas sebanyak (53\%), sedangkan jawaban responden yang menyatakan Tidak Puas sebanyak(47\%). Variabel fasilitas islamic terdapat pada pernyataan nomor 5 dengan jawaban Puas sebanyak (67\%), sedangkan jawaban responden yang menyatakan Tidak Puas sebanyak (33\%). Variabel kenyamanan pengunjung terdapat pada pernyataan nomor 7 dengan jawaban Puas sebanyak (82\%), sedangkan jawaban responden yang menyatakan Tidak Puas sebanyak $(18 \%)$.

Dari hasil wawan cara yang dilakukan peneliti banyak masyarakat yang berpendapat bahwa Masjid Islamic Center Kabupaten Rokan Hulu adalah masjid yang terindah dan masjid yang mempunyai fasilitas yang lengkap, dimana fasilitas yang bisa dilihat oleh pengunjung adalah adanya sekolah yang berbasiskan agama, baik dari taman Alquran maupun sekolah tinggi ilmu alquran sehingga masyarakat yang berkunjung merasa puas dengan keadaan yang ada, dengan bentuk dan gaya yang dipancarkan oleh masjid Islamic Center Kabupaten Rokan Hulu tersebut membuat para pengunjung merasa puas untuk berkunjung serta dapat merasakan keindahan seperti, bagi para pengunjung yang telah pernah berkunjung di kota Mekah.

Masjid Islamic Center Kabupaten Rokan Hulu merupakan masjid yang terbaik serta masjid yang ramai dikunjungi oleh masyarakat baik dari daerah tersebut sampai keluar daerah bahkan sampai ke provinsi tetangga, dan Negara tetangga, dengan demikian para pengunjung tidak bosan- bosan untuk berkunjung ke masjid tersebut dengan alasan rindu dengan keadaan yang ada ditanah suci Mekah. Pendapat para pengunjung yang dimana para pengunjung setiap berkunjung ke masjid Islamic Center Kabupaten Rokan Hulu maka merasa senang dan bangga.

\section{KESIMPULAN}

Berdasarkan hasil penelitian yang dilakukan pada di Islamic Center Kabupaten Rokan Hulu tercapai sesuai dengan hasil penelitian dapat disimpulkan bahwa :

1. Keadaan lokasi Islamic Center yang dirasakan strategis sehingga pengunjung tertarik dan merasa puas sesuai dengan hasil yang didapatkan yaitu Memberikan tontonan tentang proses pembuatan Islamic Center 
Kabpaten pengunjung memberi nilai 53\% merasa puas, sedangkan menyatakan tidak puas yaitu (47\%). Jawaban kedua yaitu Pengunjung selalu kehilangan sepatu atau alas kaki dengan jumlah frekuensinya jawaban puas yaitu (53\%), sedangkan menyatakan tidak puas yaitu (47\%). Pertanyaan ketiga Pengunjung selalu menjumpai air kran mati setiap mau berwuduk dengan jumlah frekuensinya jawaban puas yaitu (38\%), sedangkan menyatakan tidak puas yaitu $(62 \%)$.

2. Faktor kenyamanan pengunjung sangat lah rendah sesuai dengan aitem wawancara yang dilakukan peneliti Pengunjung selalu kehilangan sepatu atau alas kaki dengan nilai yang didapatkan adalah sebesar $67 \%$ sehingga pengunjung merasa resah atas kejadian yang terjadi.

\section{Saran}

Berdasarkan hasil penelitian yang dilakukan pada Islamic Center Kabupaten Rokan Hulu dapat dijelaskan sebagai berikut:

1. Bagi Pegawai Islamic Center disarankan agar memberikan kepusan kepada pengunjung.

2. Bagi petugas yang terkait dalam mengelola Islamic Center agar lebih meningkatkan lagi pelayanan sehingga hasilnya optimal.
3. Bagi para pengunjung agar menjaga kebersihan dan keamanan dalam rangka berkunjung.

\section{REFERENSI}

Arikunto. 2007. Metodologi Penelitian, Jakarta : Rineka Cipta

Aini Yulfita. 2013. Pengaruh motivasi internal dan lingkungan kerja terhadap kinerja karyawan universitas Pasir Pengaraian Jurnal Ilmiah Cano Ekonomos Vol. 2. Rokan Hulu-Riau : Fakultas Ekonomi Universitas Pasir Pengaraian

Aswar. 2005. Manajemen Pemasaran dan Pemasaran Jasa. Bandung : Alfabeta.

Feliatra. dkk. 2011. Metodologi Penelitian Persiapan Bagi peneliti Pemula, Pekan Baru:Faperika Perss

Ghozali.2005. Ekonomi Public dan Aplikasi Ekonomi BPEJ-UGM. Jogjakarta

Hardiyansyah. 2011. Kualitas Pelayanan Publik Konsep, Dimensi, Indikator dan mplementasinya. Yokyakarta : Gava Media.

Hikmatus Saadah Nur, 2007. Pengaruh Kualitas Pelayanan Terhadap Kepuasan penumpang. Universitas Islam Negri (UINJ) Malang

Hurriyati, Ratih. 2010. Bauran Pemasaran dan Loyalitas Konsumen. Alfabeta: Bandung

Irwan. 2006. Pengantar Ilmu Ekonomi Mikr, CAPS : Jakarta

Klother Philip dan Lanekeller Kevin. 2009. Manajemen Pemasaran,Jilid II Alih

Malayu S.P. Hasibuan. 2014. Manajemen Sunber Daya Manusia, Jakarta : Bumi Akrasa

Mardalis. 2014. Metode Penelitian Suatu Pendekatan Proposal, Jakarta : Rineka Cipta.

Narbuko Cholid \& Abu Ahmadi. 2009, Metode Penelitian, Jakarta : Bumi Aksara.

Nugroho. 2013. Metode Penelitian dalam Teori \& Praktek, Jakarta : Rineka Cipta

Notoatmodjo. 2010. Metode Penelitian, Jakarta : 
Bumi Aksara.

Peraturan Pemerintah Republik Indonesia Nomor 50 Tahun 2011 tentang Rencana Induk Pembangunan Kepariwisataan Tahun 2010-2015.

Peraturan Pemerintah Republik Indonesia Nomor 50 Tahun 2011 tersebut serta Instruksi Presiden Nomor 6 Tahun 2009 tentang Pengembangan Ekonomi Kreatif.

PT. Asuransi Ekspor Indonesia (Persero). 2009. Survey Kepuasan Pelanggan.(Skripsi)

Putri Habsari. 2010. Pengembangan alat ukur kepuasan jasa pendidikan tinggi berdasar persepsi mahasiswa di Universitas Sebelas Maret Surakarta. (Skripsi)

Putu Teja Wijaya Putra. 2011. Pengaruh Kualitas Jasa Dan Kepuasan Pelangan Terhadap Rekomendasi Dari Mulut Ke Mulut Pada Rumah Sakit Anak Dan Ibu Permata Hati Klungkung. (Skripsi).

Richa Widyaningtyas. 2010 Faktor-faktor yang mempengaruhi loyalitas serta dampaknya pada kepuasan konsumen dalam menggunakan jasa kereta api harina(Skripsi).

Rivai Veithzal \& Ella Jauvani Sagala. 2011. Manajemen Sumber Daya Mannusia untuk Perusahaan, Jakarta : Rajawali Pers

Saadah. 2007. Manajemen Pemasaran. Jakarta: PT. Prenhalindo.

Seprini. 2013. Pengaruh Budaya Organisasi Terhadap Kinerja Pegawai Inspektorat Kabupaten Rokan Hulu Jurnal Ilmiah Cano Ekonomos Vol. 2. Rokan Hulu-Riau : Fakultas Ekonomi Universitas Pasir Pengaraian.

Subagyo Joko. 2011. Metode Penelitian Dalam Teori \& Paraktek, Jakarta Rineka Cipta

Suetojo Siswanto. 2012. Manajemen Bisnis Perusahaan Di Indonesia yang Efektif, Jakarta : PT. Damar Mulia Pustaka

Sugiyono. (2010). Metode Penelitian Kuantitatif, Kualitatif dan $R$ \& $D$. Bandung : Alfabeta.

2012. Metode Penelitian Bisnis, Bandung : ALFABETA
2008. Metode Penelitian Bisnis, Bandung : ALFABETA

Susilo Martoyo. 2007. Manajemen Sumber Daya Manusia, Jakarta : Rineka Cipta

Sondang P. Siagian. 2008. Manajemen Sumber Daya Manusia. Jakarta : Bimi Aksara

Sefnedi. 2010. Desain Produk dan Jasa. Bahan Ajar Manajemen Operasional. Magister Manajemen UNP.

Suharsimi Arikunto 2010. Prosedur Penelitian Jakarta : Rineka Cipta

Supranto. J. 2011. Pengukuran Tingkat Kepuasan Pelanggan Jakarta : Rineka Cipta

2008. Pengukuran Tingkat Kepuasan Pelanggan Jakarta : Rineka Cipta

Trisno Musanto. 2010. Faktor-Faktor Kepuasan Pelanggan dan Loyalitas Pelanggan: Studi Kasus pada CV. Sarana Media Advertising Surabaya. (Skripsi)

Wiratna.2014, Manajemen Pemasaran Dasar Konsep dan Strategi, Jakarta: PT. Raja Grafindo. 